\section{The University of Arizona Library} has received $\$ 123,672$ from the Institute of Museum and Library Services for a two-year digital project that will create the Arizona Electronic Atlas. This Web-based interactive state atlas will be accessible to all levels of users. The project will develop a model workflow and methodology that other organizations can use to develop their own Web-based atlases and other products using Geographic Information Systems (GIS) technologies.

\section{The University of Michigan has been}

awarded a grant for $\$ 860,000$ from the Andrew W. Mellon Foundation to support postdoctoral fellowships focusing on the use of the university's research collections. With the grant, and $\$ 140,000$ in matching funds from the Office of the University's Provost, a public goods program that will offer both junior and senior postdoctoral fellowships will be instituted for a four-year term. The fellowships, which are intended for scholars in the fields of the humanities and related social sciences, are expected to attract scholars to the university whose work would be derived from the collections housed on campus. Further information about the application process may be found at http://www.umich.edu/ $\sim$ provost/publicgoods/.

\section{Cornell University Library (CUL) has} received an $\$ 830,000$ grant from the Andrew W. Mellon Foundation to digitize the remaining records in its card catalog and add them to its online catalog. In the 1970 s, CUL began converting records from card to machine readable format, and, since 1983 , all records for newly acquired materials have been added to the library's online catalog. However, more than 276,000 bibliographic records for items in Cornell's collections, including a large number of humanities and social science titles, exist only on paper cards filed in

Ed. note: Send your news to: Grants \& Acquisitions, C\&RL News, 50 E. Huron St., Chicago, IL 60611-2795; e-mail: ayoung@ala.org. traditional, heavy wooden cabinets. This means that these titles also have no electronic bibliographic record in national or international databases. CUL will convert all of its card catalog records for titles classified according to the Library of Congress classification system. The project will be completed early in 2005.

\section{Acquisitions}

\section{Emory University has acquired the}

papers of composer and choral director William Levi Dawson. Described as the "Dean of African American Choral Composers," Dawson is world renowned for his arrangements of Negro spirituals and for his composition of the Negro Folk Symphony, premiered in 1934 by the Philadelphia Symphony Orchestra under the direction of Leopold Stokowski. The collection includes the scores and sheet music of other African American composers, with correspondence from John W. Work, William Grant Still, George Washington Carver, Leontyne Price, and Fanny and Ralph Ellison. It also includes hundreds of recordings from African American church, high school, college, and university choirs and a wide array of classical, jazz, blues, and popular music on 78- and 33-rpm phonodisc, as well as reel-toreel, cassette, and 8-track tape. Dawson's library included books of music theory and history (most notalbly a first edition of the novel Invisible Man by Ralph Ellison) and hundreds of scores of classical music. The papers are expected to be open for research early in 2003.

("Preservation News" continued from page 215)

Free copies of this issue are available from ArchitectureBoston, 52 Broad St, Boston, MA 02109-4301; phone: (617) 9511433; fax: (617) 951-0845; Web: http:// Www architects.org. 


\section{ATLA

American

\section{Catholic Periodical Literature Index (CPLI) on CD-ROM}

\section{Edition available in May}

Sister Rebecca Abel of the North American College in Vatican City shared this endorsement about the new Windows version of CPLI:

I don't know exactly "who" to thank but after completing the installation of our CD's for the ATLA and CPLI indexes-I feel I must thank someone. The "User-Friendly" quality is superb! Thanks to all who are "making my work easier!" After working with computers and technology over the past 20 years, I can appreciate the work and effort you expended to reach this end. It was well worth it! Bravo!!!

The Catholic Periodical Literature Index (CPLI) on CD-ROM provides more than 350,000 bibliographic citations from Catholic periodicals, essay collections, and monographs. CPLI features historical information on the contributions of the Catholic Church to western civilization and world cultures as well as current announcements and contemporary thought on a variety of issues including:

- Medical issues (abortion, euthanasia, ethics)

- Social services, policy, welfare

- Scholastic philosophies

- Theology (ancient, contemporary, and feminist)

- Canon law

- Organizations

- Spirituality (meditation, prayer, monasticism)

- Liturgy (calendar, sacraments, ceremonies)

- Papal documents

Take advantage of this special introductory offer: subscribe to the Catholic Periodical Literature Index (CPLI) on CD-ROM, 2002

\section{Mention this ad and receive a $\$ 100$ discount}

Visit our web site at http://www.atla.com/products or call Melody de Catur on our toll free number 1-888-665-ATLA today 